\title{
Serum and Urine Free Light Chain Cut-off Detection for a Rational Employment of the Bence-Jones Proteinuria Test in Presence of Monoclonal Gammopathy
}

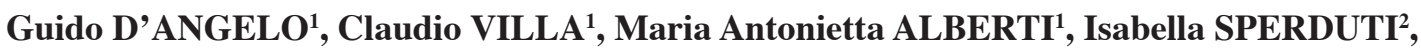 \\ Annarita SFERRAZZO ${ }^{1}$, Silvia VILLA ${ }^{1}$ \\ ${ }^{1}$ Laboratorio di Chimica-Clinica, Ematologia e Microbiologia Azienda Socio Sanitaria Territoriale (ASST) \\ della Valle Olona Ospedale di Gallarate, Varese \\ ${ }^{2}$ Unità di Biostatistica, Istituto Nazionale Tumori Regina Elena, Roma, ITALY
}

\begin{abstract}
We evaluated whether, in presence of monoclonal gammapathy (MG), serum and urinary free light chains (FLCs) measurement may limit the Bence-Jones proteinuria (BJP) test employement, that is affected by pre-analytical, analytic and post-analytical problems. From March to May 2016, 89 patients who were refered to our laboratory for BJP assay with suspected plasma cell dyscrasia, were

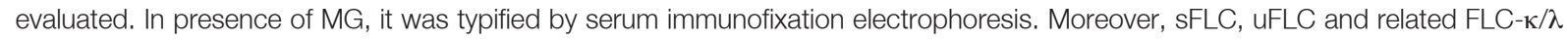
ratio, as well as glomerular filtration rate (eGFR), were also measured. Patients with MG-к: the ROC curves analysis showed an ac-

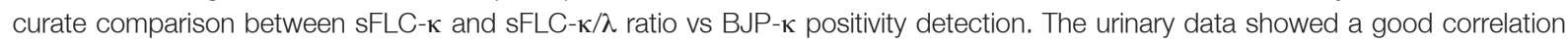

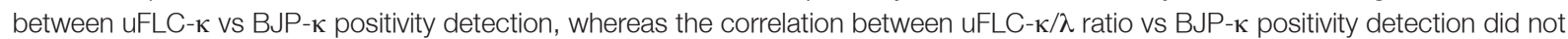
show satisfactory results. Patients with MG- $\lambda$ : comparing sFLC- $\lambda$ and SFLC- $\kappa / \lambda$ ratio vs BJP- $\lambda$ positivity detection, the ROC curves analysis showed a good correlation. The urinary data of UFLC- $\lambda$ vs BJP- $\lambda$ positivity detection and $\mathrm{UFC}-\kappa / \lambda$ ratio vs BJP- $\lambda$ positivity detection did not show satisfactory results for sensitivity and specificity. The absolute values of "k" and " $\lambda$ " FLC vs BJP positivity detection, statistically are more significant than the FLC- $\kappa / \lambda$ ratio. The aggregate data of UFLC, $[\mathrm{uFLC}-\Sigma(\kappa+\lambda)]$, identified a statistically significant median value for the detection of BJP positivity. Although the study statistically showed the possibility in same cases to optimize the BJP test employment, further validations to confirm the objectives by us defined are needed.
\end{abstract}

Keywords: Plasma cell dyscrasia, Monoclonal gammopathy, Serum free light chain, Urine free light chain, Bence-Jones proteinuria

ÖZET

Monoklonal Gammopati Varığında Bence-Jones Proteinüri Testinin Akılcı Kullanımı İçin Serum ve İdrar Serbest Hafif Zincir Cut-off Tespiti

Monoklonal gammapatinin varlığında, serum ve idrar serbest hafif zincirlerin (FLC) ölçümü, pre analitik, analitik ve post-analitik problemlerden etkilenen Bence-Jones proteinüri (BJP) testi kullanımını sınıllayıp sınıllamayacağını değerlendirdik. Mart-Mayıs 2016 tarihleri arasında, plazma hücre diskrazisi şüphesi ile BJP testi için laboratuarımıza gönderilen 89 hasta değerlendirildi. MG varlığında, serum

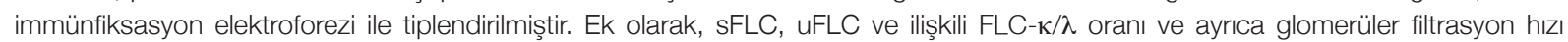

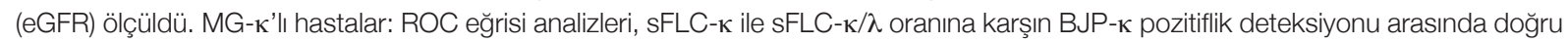

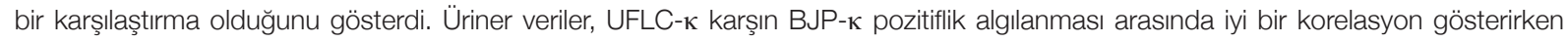

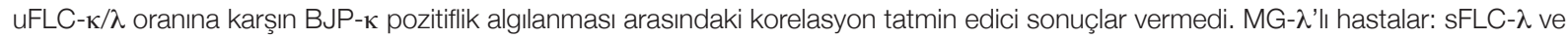
SFLC- $\kappa / \lambda$ oranına karşın BJP- $\lambda$ pozitiflik algılanması karşılaştııılığında, ROC eğrisi analizleri iyi korelasyon gösterdi. UFLC- $\lambda$ ile BJP- $\lambda$ pozitiflik deteksiyonu ve UFC- $/ \lambda$ oranına karşın BJP- $\lambda$ pozitiflik algılanmasının üriner verileri, sensitivite ve spesifisite açısından tatmin edici sonuçlar vermedi. " $\kappa$ ” ve " $\lambda$ ” FLC'ye karşın BJP pozitiflik algılanması mutlak değerleri, istatistiksel olarak FLC- $\kappa / \lambda$ oranından daha önemlidir. UFLC, [UFLC- $\Sigma(\kappa+\lambda)$ ] toplam verisi, BJP pozitifliği saptanması/algllanmasında istatistiksel olarak anlamlı bir medyan/ortalama değer tespit etti. Çalışma, aynı vakalarda BJP testi kullanımın optimize etme intimalini istatistiksel olarak göstermiş olmasına rağmen, tanımladığımız hedefleri doğrulamak için daha fazla geçerliliğe ihtiyaç vardır.

Anahtar Kelimeler: Plazma hücre diskrazisi, Myoklonal gamopati, Serum serbest hafif zinciri, İdrar serbest hafif zinciri, Bence-Jones proteinürisi 


\section{INTRODUCTION}

In order to assemble the whole immunoglobulin, heavy chains (HCs) and light chains (LCs) synthesis takes place in an orderly manner, as well as their intracellular assembly. ${ }^{1}$ As part of this process, low concentrations of free LCs (FLCs) are normally present in the serum of healthy subjects, but, when the LCs are compared to HCs production, physiologically they are produced in surplus.

The monoclonal sFLCs may be increased not only in plasma cell dyscrasias (PCDs) ${ }^{2}$, but also in the B-cell lymphomas. ${ }^{3,4}$

In PCD not only is the kidney function often affected, but it is also imparied due to FLC catabolism that takes place exclusively in the kidney. ${ }^{5}$ Kidney tubular abnormality is present in more than $98 \%$ of patients with PCD in whom Bence-Jones proteinuria (BJP) is $>1 \mathrm{~g} / 24 \mathrm{~h}$; therefore, the tubular lesion associated with LCs overexcretion is always present. $^{6}$

The peculiar metabolism of FLCs makes often the Bence-Jones proteinuria (BJP) detection complicated, because the same FLCs are part of the BJP. Moreover, the BJP detection is "sample-dependent".

The study was aimed to assess whether, in presence of monoclonal gammopathy (MG), regardless of plasma cell dyscrasia, the free light chains (FLCs) measurement, as well as FLC- $\kappa / \lambda$ ratio, in both serum (sFLC) and urine (uFLC), may limit the BJP test employment.

\section{MATERIAL AND METHODS}

From March to May 2016, 122 patients who attended our laboratory for a suspected PCD were evaluated. For each patient, BJP and serum proteins electrophoresis (SPE) assays were performed. In case of monoclonal gammopathy (MG), in addition to SPE, serum immunofixation electrophoresis (IFE), serum and urine FLCs, as well as FLC- $/ / \lambda$ ratio and alleged glomerular filtration rate (eGFR), by CK-EPI formula ${ }^{7}$, were also measured. Serum and urine samples were stored at $-80^{\circ} \mathrm{C}$ and, for each sample, sFLC and uFLC in a single run were measured. Out of 122 patients recruited, 33 with
eGFR $<60 \mathrm{~mL} / \mathrm{min}$ were ruled out. Of the remaning 89 patients enrolled, 51 were males, aged between 33 and 83 years, median 65 , and 38 were females, aged between 39 and 94 years, median 68.5.

The SPE were assessed utilizing Capillarys Protein(E) 6 instrument (Sebia ${ }^{\circledR}$, Florence, Italy), whereas the IFE was performed on Hydragel 4 IF instrument (Sebia ${ }^{\circledR}$, Florence, Italy). The BJP was detected by urine immunofixation electrophoresis (uIFEP) using a semi-automated agarose electrophoresis system (Hydragel 4 BJ and Hydrasys; Sebia ${ }^{\circledR}$, Florence, Italy). For BJP detection, using Hydrasys kit, the sensitivity limit stated by the manufacturer is $50 \mathrm{mg} / \mathrm{L}$. In order to improve the sensitivity, the samples may be concentrated 10 or 25 times, according to the proteinuria value.

In serum and urine, " $\kappa$ " and " $\lambda$ " FLCs were measured by means of Binding Site ${ }^{\circledR}$ kit (The Binding Site ${ }^{\circledR}$ Group Ltd., Birmingham, UK), (sFLC-k reference values (r.v.) 95th percentile $=3.3-19.4$ $\mathrm{mg} / \mathrm{L} ; \mathrm{sFLC}-\lambda$ r.v. 95 th percentile $=5.7-26.3 \mathrm{mg} / \mathrm{L}$; $s F L C-k / \lambda$ ratio $r . v=0.26-1.65$, whereas $u F L C-k$ r.v. 95 th percentile $=0.39-15.1 \mathrm{mg} / \mathrm{L}$; uFLC- $\lambda$ r.v. 95th percentile $=0.81-10.1 \mathrm{mg} / \mathrm{L} ; \mathrm{uFLC}-\mathrm{k} / \lambda$ ratio r.v.= 0.461-4.00). After method implementation, the FLCs dosage was performed on an automatic analyzer ${ }^{8}$, Olympus Au480 (Beckman Coulter ${ }^{\circledR}$, Inc. CA, USA).

In Table 1 serum and urinary immunological features of 89 patients enrolled are summarized.

\section{Statistical Analysis}

Continuous data, as mean and standard deviation, or median and range, was reported. Binary data, as frequency and percentage values, ware also reported. Performance characteristics (sensitivity, specificity, Areas Under the Curves (AUC) and optimal cut-off for continuous variables) were evaluated by computing Receiver Operating Characteristic (ROC) curves.

Quantitative variables were compared using the non-parametric Mann-Whitney test or Student's ttest. A p-value $\leq 0.05$ was considered statistically significant. The SPSS ${ }^{\circledR}$ (21.0) statistical program was used for all the analyses. 
International Journal of Hematology and Oncology

\begin{tabular}{|c|c|c|c|c|}
\hline Number patients & MG & BJP-k Present & BJP- $\lambda$ Present & BJP Absent \\
\hline 35 & lgG-k & 16 & 0 & 19 \\
\hline 19 & $\lg G-\lambda$ & 0 & 4 & 15 \\
\hline 3 & $\operatorname{lgM}-\mathrm{k}$ & 1 & 0 & 2 \\
\hline 2 & $\operatorname{lgM}-\lambda$ & 0 & 0 & 2 \\
\hline 6 & $\lg A-k$ & 1 & 0 & 5 \\
\hline 1 & $\lg A-\lambda$ & 0 & 0 & 1 \\
\hline 9 & Mixed $\left({ }^{\star}\right)$ & 1 & 1 & 7 \\
\hline 14 & Absent MG & 0 & 0 & 14 \\
\hline Tot. 89 & & 19 & 5 & 65 \\
\hline
\end{tabular}

The study, performed in accordance with the Declaration of Helsinki and complying with local laws, did not require informed consent or Ethics Committee approval because it was carried out employing samples obtained after routine analysis.

\section{RESULTS}

The measures of sFLC and uFLC and their correlation with BJP detection, whether it was present or absent, are summarized in Table 2.

\section{Serum Data Analysis \\ SFLC $-\kappa$ vs BJP- $\kappa$ positivity detection in patients with monoclonal gammopathy-k}

Taking into account the dosage of sFLC- $\kappa$ vs BJP$\mathrm{k}$ in 67 patients, including 44 patients with MG-k, 9 patients with mixed MG and 14 patients without monoclonal gammopathy, the areas under ROC curves (AUC) were 0.91 (95\% I.C. : 0.82 - 0.99) (Figure 1). The sensitivity and specificity, with an optimal cut-off for sFLC-k dosage $\geq 45.7 \mathrm{mg} / \mathrm{L}$, were $78.9 \%$ and $89.1 \%$, respectively; the positive likelihood ratio (+LR) was 7.26.

\begin{tabular}{|c|c|c|c|c|}
\hline \multirow[t]{2}{*}{ FLC (mg/L) } & \multicolumn{2}{|c|}{ BJP-k $(n=67)$} & \multicolumn{2}{|c|}{ BJP- $-\lambda(n=45)$} \\
\hline & Absent $(n=48)$ & Present $(n=19)$ & Absent $(n=40)$ & Present $(n=5)$ \\
\hline $\begin{array}{l}\text { sFLC-k median (median range) } \\
(\text { r.v. }=3.3-19.4 \mathrm{mg} / \mathrm{L})\end{array}$ & $20.2(3.2-90.5)$ & $101.9(14.2-2335)$ & $15.9(6.5-135.9)$ & $6.1(3.2-16.5)$ \\
\hline $\begin{array}{l}\text { sFLC- } \lambda \text { median (median range) } \\
(\text { r.v. }=5.7-26.3 \mathrm{mg} / \mathrm{L})\end{array}$ & $6.4(3.0$ - 23.6) & $7.3(2.7-180.8)$ & $9.8(3.0-104.4)$ & $116.0(77.3-7807)$ \\
\hline $\begin{array}{l}\text { sFLC-k/ } \lambda \text { ratio median (median } \\
\text { range) }(r . v .=0.26-1.65)\end{array}$ & $2.49(1.07-30.2)$ & $13.4(2.12-778)$ & $1.76(0.3-10.47)$ & $0.04(0.0008-0.14)$ \\
\hline $\begin{array}{l}\text { uFLC-k median (median range) } \\
(\text { r.v. }=0.39-15.1 \mathrm{mg} / \mathrm{L})\end{array}$ & $14.4(1.0-630.2)$ & $175.3(23.0-605.7)$ & $10.7(1.0-630.2)$ & $10.2(3.2-66.2)$ \\
\hline $\begin{array}{l}\text { uFLC- } \lambda \text { median (median range) } \\
(\text { r.v. }=0.81-10.1 \mathrm{mg} / \mathrm{L})\end{array}$ & $1.3(0.3-77.8)$ & $3.0(1.1-37.3)$ & $1.8(0.6-7.80)$ & $6.9(2.3-32.1)$ \\
\hline $\begin{array}{l}\text { uFLC-k/ } \lambda \text { ratio median (median } \\
\text { range) }(r . v .=0.461-4.00)\end{array}$ & $8.46(1.67-42.4)$ & $50.1(3.0$ - 403.8) & $7.1(1.3-22.3)$ & $1.4(0.3-9.6)$ \\
\hline
\end{tabular}




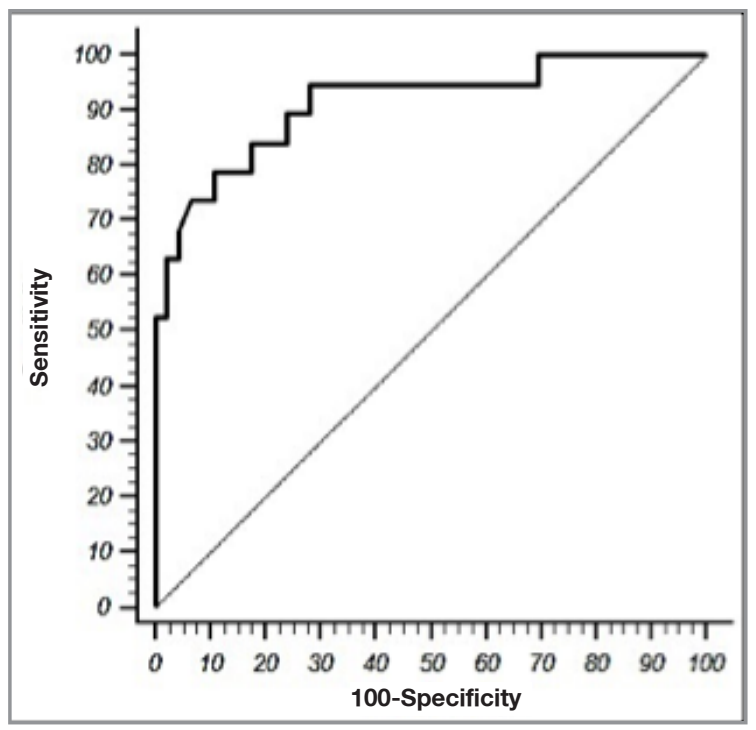

Figure 1. ROC curve analysis for sFLC-k dosages vs BJP-k detection. (Number of patients 67, considering patients with MG-k, patients with mixed MG and patients with MG absent. ( $\mathrm{MG}=$ Monoclonal Gammopathy).

SFLC- $\kappa / \lambda$ ratio vs BJP- $\kappa$ positivity detection in patients with monoclonal gammopathy-k

Always in 67 patients referred above, taking into consideration $\mathrm{SFLC}-\kappa / \lambda$ ratio vs BJP- $\kappa$ positivity detection, the ROC curves showed an AUC $=0.84$ (95\% I.C. : 0.74 - 0.95) (Figure 2). The sensitivity and specificity, with an optimal cut-off for sFLC$\kappa / \lambda$ ratio $\geq 6.3$, were $68 \%$ and $87 \%$, respectively; $+\mathrm{LR}=5.2$.

\section{sFLC- $\lambda$ vs BJP- $\lambda$ positivity detection in patients} with monoclonal gammopathy- $\lambda$

Taking into consideration sFLC- $\lambda$ vs BJP- $\lambda$ positivity detection in 45 patients, including 22 patients with MG- $\lambda, 9$ patients with mixed MG and 14 patients without MG, the ROC curves showed an AUC $=0.99$ (95\% I.C. : 0.96-1.00) (Figure 3). The sensitivity and specificity, with an optimal cut-off for sFLC- $\lambda$ dosage $\geq 39.7$, were $100 \%$ and $97.1 \%$, respectively; $+\mathrm{LR}=35.0$.

SFLC- $\kappa / \lambda$ ratio vs BJP- $\lambda$ positivity detection in patients with monoclonal gammopathy- $\lambda$

Always in 45 patients referred above, taking into consideration $\mathrm{SFLC}-\kappa / \lambda$ ratio vs $\mathrm{BJP}-\lambda$ positivity detection, the ROC curves showed an AUC $=1.0$

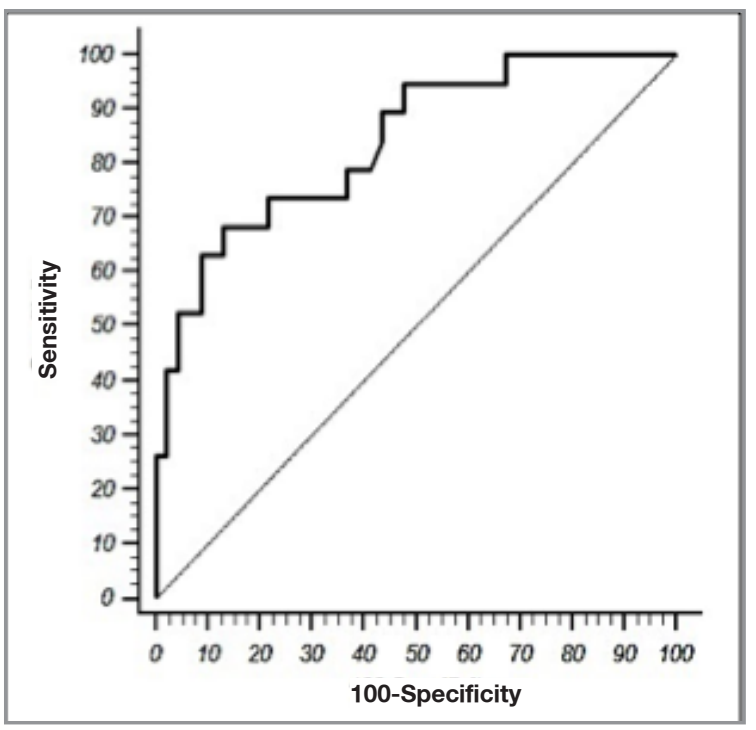

Figure 2. ROC curve analysis for $s F L C-k / \lambda$ ratio vs BJP-k detection. (Number of patients 67 , considering patients with $M G-k$, patients with mixed MG and patients with MG absent. ( $M G=$ Monoclonal Gammopathy).

(95\% I.C. : 0.95 - 1.00) (Figure 4). The sensitivity and specificity, with an optimal cut-off for sFLC$\kappa / \lambda$ ratio $\leq 0.31$, were $100 \%$ and $97.3 \%$, respectively; $+\mathrm{LR}=37.0$.

\section{Urine Data Analysis}

uFLC- $\kappa$ vs BJP- $\kappa$ positivity detection in patients with monoclonal gammopathy-k

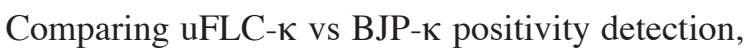
always in 67 patients including patients with MG$\mathrm{k}$, mixed monoclonal gammopathy and patients without monoclonal gammopathy, as above reported, the ROC curves showed an AUC $=0.91(95 \%$ I.C. : $0.82-1.00)$. The sensitivity and specificity, with an optimal cut-off for uFLC- $\kappa$ dosage $\geq 52.6$, were $88.9 \%$ and $85.7 \%$, respectively; $+\mathrm{LR}=6.2$.

uFLC- $\kappa / \lambda$ ratio vs BJP- $\kappa$ positivity detection in patients with monoclonal gammopathy-k

In a comparative analysis between $\mathrm{uFLC}-\kappa / \lambda$ ra-

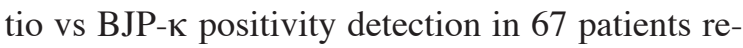
ferred above, the ROC curves showed an AUC = 0.83 (95\% I.C. : $0.64-1.00)$. The sensitivity and specificity, with an optimal cut-off for $\mathrm{uFLC}-\kappa / \lambda$ ratio $\geq 11.3$, were $88.9 \%$ and $74.3 \%$, respectively; $+\mathrm{LR}=3.5$. 


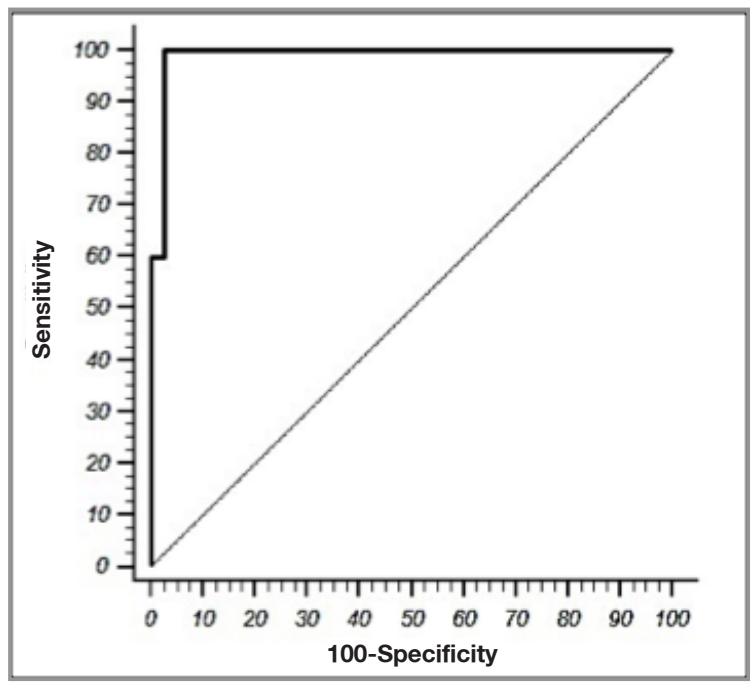

Figure 3. ROC curve analysis for SFLC- $\lambda$ vs BJP- $\lambda$ detection. (Number of patients 45 , considering patients with MG- $\lambda$, patients with mixed $M G$ and patients with $M G$ absent. (MG = Monoclonal Gammopathy).

uFLC- $\lambda$ vs BJP- $\lambda$ positivity detection in patients with monoclonal gammopathy- $\lambda$

When $\mathrm{uFLC}-\lambda$ data was compared with BJP- $\lambda$ positivity detection in 45 patients, including patients with MG- $\lambda$, patients with mixed MG and patients without monoclonal gammopathy, the ROC curves showed an $\mathrm{AUC}=0.82$ (95\% I.C. : 0.64 - 1.00). The sensitivity and specificity, with an optimal cut-off for uFLC- $\lambda$ dosage $\geq 5.2$, were $66.7 \%$ and $80.8 \%$, respectively; $+\mathrm{LR}=3.5$.

\section{$\mathrm{uFLC}-\kappa / \lambda$ ratio vs $\mathrm{BJP}-\lambda$ positivity detection in patients with monoclonal gammopathy- $\lambda$}

Comparing $\mathrm{uFLC}-\kappa / \lambda$ ratio vs BJP- $\lambda$ positivity detection, always in 45 patients referred above, the ROC curve showed an AUC $=0.73$ (95\% I.C.: 0.32 - 1.00). The sensitivity and specificity, with an optimal cut-off for uFLC- $\kappa / \lambda$ ratio $\leq 1.5$, were $66.7 \%$ and $96.2 \%$, respectively; $+\mathrm{LR}=17.6$.

In Table 3 the summary of the statistical analysis is reported.

uFLC aggregated data, [uFLC- $\Sigma(\kappa+\lambda)$ ], vs BJP positivity detection.

As part of uFLCs analysis, the aggregated data, [uFLC- $\Sigma(\kappa+\lambda)]$, vs BJP positivity detection was

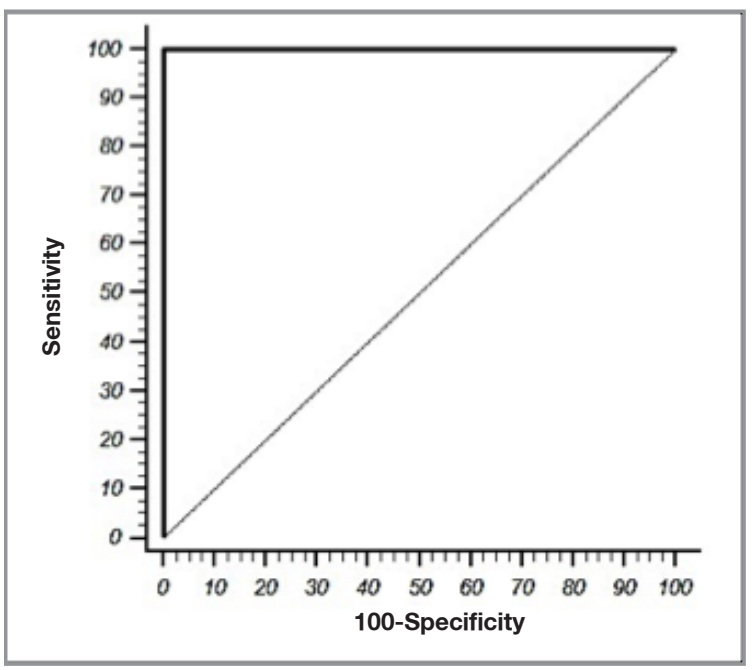

Figure 4. $\mathrm{ROC}$ curve analysis for SFLC- $k / \lambda$ ratio vs BJP- $\lambda$ detection. (Number of patients 45, considering patients with MG$\lambda$, patients with mixed MG and patients with MG absent. (MG = Monoclonal Gammopathy).

assessed. In presence of BJP detection, the median value of $[\mathrm{uFLC}-\Sigma(\kappa+\lambda)]$ was about 10 times higher compared to the median value found in patients in whom BJP was not detected, $(\mathrm{p} \leq 0.0001)$ (Table 4).

\section{DISCUSSION}

The FLC assay is a landmark test included in national and international guidelines $\mathrm{s}^{9,10}$ for diagnosis, prognosis and monitoring in the $\operatorname{PCDs}^{11,12,13}$, as well as BJP test.

It's well known that the BJP test is affected by significant pre-analytical, analytical and post-analytical problems ${ }^{14,15,16}$, therefore, its limited and rational employment in same cases could avoid the aforementioned problems.

Since FLCs catabolism takes place exclusively in the kidney, for this reason we believed that to recruit patients with normal eGFR was appropriate. ${ }^{17,18}$

The ROC curves analysis showed that comparing sFLC- $\kappa$ and $\mathrm{sFLC}-\kappa / \lambda$ ratio vs BJP- $\kappa$ positivity detection, the comparison was accurate $(\mathrm{AUC}=0.91$ and 0.84 , respectively), with a $+\mathrm{LR}$ moderately useful $(+\mathrm{LR}=7.26$ and 5.25, respectively). 
International Journal of Hematology and Oncology

\begin{tabular}{|c|c|c|c|c|c|c|c|}
\hline $\begin{array}{l}\text { Monoclonal } \\
\text { Gammopathy }\end{array}$ & $\begin{array}{l}\text { sFLC and uFLC vs } \\
\text { BJP detection }\end{array}$ & $\begin{array}{l}\text { Cut-off } \\
\text { (mg/L) }\end{array}$ & AUC & Sensitivity & Specificity & 95\% I.C. & +LR \\
\hline \multirow[t]{8}{*}{ MG-k } & sFLC-k vs BJP-k & & & & & & \\
\hline & (n. patients 67) ${ }^{\star}$ & $\geq 45.7$ & 0.91 & 78.9 & 89.1 & $0.82-099$ & 7.26 \\
\hline & sFLC- $\kappa / \lambda$ ratio vs BJP-k & & & & & & \\
\hline & (n. patients 67) & $\geq 6.3$ & 0.84 & 68 & 87 & $0.74-0.95$ & 5.2 \\
\hline & uFLC-k vs BJP-k & & & & & & \\
\hline & (n. patients 67) & $\geq 52.6$ & 0.91 & 88.9 & 85.7 & $0.82-1.00$ & 6.2 \\
\hline & uFLC- $\kappa / \lambda$ ratio vs BJP-k & & & & & & \\
\hline & (n. patients 67) & $\geq 11.3$ & 0.83 & 88.9 & 74.3 & $0.64-1.00$ & 3.5 \\
\hline \multirow[t]{8}{*}{ MG- $\lambda$} & sFLC- $\lambda$ vs BJP- $\lambda$ & & & & & & \\
\hline & $(\text { n. patients } 45)^{\star \star}$ & $\geq 39.7$ & 0.99 & 100 & 97.1 & $0.96-1.00$ & 35.0 \\
\hline & sFLC- $\kappa / \lambda$ ratio vs BJP- $\lambda$ & & & & & & \\
\hline & (n. patients 45) & $\leq 0.31$ & 1.00 & 100 & 97.3 & $0.95-1.00$ & 37.0 \\
\hline & uFLC- $\lambda$ vs BJP- $\lambda$ & & & & & & \\
\hline & (n. patients 45) & $\geq 5.2$ & 0.82 & 66.7 & 80.8 & $0.64-1.00$ & 3.5 \\
\hline & uFLC- $\kappa / \lambda$ ratio vs BJP- $\lambda$ & & & & & & \\
\hline & (n. patients 45) & $\leq 1.5$ & 0.73 & 66.7 & 96.2 & $0.32-1.00$ & 17.6 \\
\hline
\end{tabular}

With regards to the comparison between sFLC- $\lambda$ and $\mathrm{sFLC}-\kappa / \lambda$ ratio vs BJP- $\lambda$ positivity detection, the ROC curves analysis showed an $\mathrm{AUC}=0.99$ and 1.0 , respectively.

Even the ROC curves analysis of urinary data showed a good correlation between $\mathrm{uFLC}-\kappa$ vs $\mathrm{BJP}-\kappa$ positivity detection $(\mathrm{AUC}=0.91 ;+\mathrm{LR}=$ 6.2), whereas the correlation between $\mathrm{uFLC}-\kappa / \lambda$ ratio vs $B J P-\kappa$ positivity detection did not show satisfactory results $(\mathrm{AUC}=0.81 ;+\mathrm{LR}=3.1)$.
Also urine analysis of uFLC $-\lambda$ vs BJP- $\lambda$ positivity detection and $\mathrm{uFC}-\kappa / \lambda$ ratio vs always BJP- $\lambda$ positivity detection did not show satisfactory results for sensitivity and specificity $(\mathrm{AUC}=0.82$ and 0.73 , respectively).

Concerning the samples with MG- $\lambda$ and BJP- $\lambda$ positivity, they were not representative; furthermore, this is supported epidemiologically by the detection of fewer patients with MG- $\lambda$ compared with MG-к patients.

Table 4. Comparison between aggregated data of uFLCs, [uFLC- $\Sigma(\kappa+\lambda)]$, vs BJP detection

\begin{tabular}{|l|l|l|l|}
\hline & $\begin{array}{l}\text { BJP Absent } \\
\text { (patients n. 65) }\end{array}$ & $\begin{array}{l}\text { BJP Present } \\
\text { (patients n. 24) }\end{array}$ & $\mathrm{p} \leq 0.0001$ \\
\hline uFLC- $\Sigma(\kappa+\lambda)$ median $(\mathrm{mg} / \mathrm{L})$ & 14.15 & 118.05 & \\
\hline
\end{tabular}


The analysis of aggregate data of uFLC, [uFLC$\Sigma(\kappa+\lambda)$ ], could be an interesting diagnostic feature in our point of view. It showed that the probability to detect BJP was statistically significant in patients with a median value 8 times higher than the value found in patients in whom BJP was not detected.

Our data still showed that the absolute values of " $\kappa$ " and " $\lambda$ " FLC, in both serum and urine, compared to the BJP positivity detection, statistically are much more significant than FLC- $\kappa / \lambda$ ratio.

We still emphasize that the purpose of our study, according to the methodological setting, was principally to assess an optimal cut-off for sFLC and uFLC able to limit the BJP test employment in some cases in which monoclonal gammopathy is found. Although we identified statistically significant cut-offs able to optimize the detection of BJP positivity, further validations to confirm the objectives defined by our research are needed.

\section{REFERENCES}

1. Scott DI. Assembly of immunoglobulin G: the role of the lightchain pool. Biochem J 130: 1151-1152, 1972.

2. Yap CYF, Wong PW, Choon T. Free kappa and lambda light chains in plasma cell dyscrasias. Proceedings of Singapore Healthcare 20: 64-66, 2011.

3. Maurer MJ, Micallef INM, Cerhan JR, et al. Elevated serum free llght chains are associated with event-free and overall survival in two independent cohorts of patients with diffuse large B-Cell lymphoma. J Clin Oncol 29: 1620-1626, 2011.

4. Charafeddine KM, Jabbour MN, Kadi RH, Daher RT. Extended use of serum free light chain as a biomarker in lymphoproliferative disorders. Am J Clin Pathol 137: 890- 897, 2012.

5. Leung NRS, Rajkumar SV. Renal manifestation in plasma cell disorders. Am J Kidney Dis 50: 155-165, 2007.

6. Abraham RS, Clark RJ, Bryant SC, et al. Correlation of serum immunoglobulin free light chain quantification with urinary Bence Jones protein in light chain myeloma. Clin Chem 48: 655-657, 2002

7. Levey AS, Stevens LA, Schmid CH, et al. CKD-EPI (Chronic Kidney Disease Epidemiology Collaboration). A new equation to estimate glomerular filtration rate. Ann Intern Med 150: 604-612, 2009.

8. Bradwell AR, Carr-Smith HD, Mead GP, et al. Highly sensitive, automated immunoassay for immunoglobulin free light chains in serum and urine. Clin Chem 47: 673-680, 2001.
9. Dimopoulos M, Kyle R, Fermand JP, et al on behalf of the International Myeloma Workshop Consensus Panel 3. Guidelines for standard investigative workup: report of the International Myeloma Workshop Consensus Panel 3. Blood 117: 4701-4705, 2011.

10. Dispenzieri A, Kyle R, Merlini G, et al. International Myeloma Working Group guidelines for serum-free light chain analysis in multiple myeloma and related disorders. Leukemia 23: 215-224, 2009.

11. Siegel D, Bilotti, van Hoeven $\mathrm{KH}$. Serum free light chain analysis for diagnosis, monitoring, and prognosis of monoclonal gammopathies. Lab Medicine 47: 363-366, 2008.

12. Tosi P, Tomassetti S, Merli A, Polli V. Serum free light-chain assay for the detection and monitoring of multiple myeloma and related conditions. Ther Adv Hematol 4: 37-41, 2013.

13. Dispenzieri A, Zhang L, Katzmann JA, et al. Appraisal of immunoglobulin free light chain as a marker of response. Blood 111: 4908-4915, 2008.

14. Graziani M, Petrini C, Merlini G. Guidelines for the analysis of Bence Jones protein. Clin Chem Lab Med 41: 338-46, 2003.

15. Hill PG, Forsyth JM, Rai B, Mayne S. Serum free light chains: an alternative test to urine Bence Jones proteins when screening for monoclonal gammopathies. Clin Chem 52: 1743-1748, 2006.

16. Graziani M, Merlini G, Petrini C. IFCC Committee on Plasma Proteins; SIBioC Study Group on Proteins, Guidelines for the analysis of Bence Jones protein. Clin Chem Lab Med 41: 338-346, 2003.

17. Heher EC, Goes NB, Spitzer TR, et al. Kidney disease associated with plasma cell dyscrasias. Blood 116: 1397-1404, 2010.

18. Schmidt-Hieltjes $Y$, Elshof $C$, Roovers $L$, Ruinemans-Koerts $J$. Diagnostic reference range of $\kappa / \lambda$ free light chain ratio to screen for Bence Jones proteinuria is not significantly influenced by GFR. Europ J Haemat 96: 527-531, 2016.

\section{Correspondence:}

Guido D'ANGELO

Ematologia/Coagulazione

Laboratorio di Chimica-Clinica, Ematologia e Microbiologia

Azienda Socio Sanitaria Territoriale (ASST) della Valle Olona

Ospedale di Gallarate

Via Pastori 4, 21013 - Gallarate

VARESE / ITALY

e-mail: danguido@libero.it

Tel. +390331751456

Fax +390331751789 